\title{
Part IV: Hearing - With a New Voice: a ficto-critical response to Howard O'Hagan's Tay John
}

\author{
Debra Dudek
}

"La quatrième partie: Entendre avec une nouvelle voix » constitue une réponse critique sous la forme d'une fiction de Tay John d'Howard O'Hagan. C'est une nouvelle qui transcende la fin du texte d'O'Hagan, donnant le dernier mot au personnage féminin, Ardith Aeriola, qui n'est que très peu présente par la parole dans le roman d'O'Hagan. Tout en étant un texte de création qui a son fonctionnement propre, c'est d'abord une réponse critique à un texte qui ne donne pas voix au chapitre à une narratrice féminine. «Entendre avec une nouvelle voix » constitue la première étape d'une trajectoire narrative qui commence avec Tay John mais Dudek refuse la conclusion de cet ouvrage. Cette nouvelle conclusion permet à Ardith de dire et de redire sa propre histoire où la « mort des héros » n'est pas l'objectif du désir féminin, mais la narration permet à celles dont les histoires sont racontées de participer elles-mêmes à leur propre récit.

The time of this in its ending, in women's time, is 1913 in the winter, and its place is outside the known, the named world, near a nurturing river, beneath a wise mountain, beside a shadowy lake. Here an empty body does not mean death. Here is a place where a woman might speak.

Emerging from the teepee, I stretched my limbs far far in front of my body in the brisk morning air. Neck extended back the weight of my hair reached for the earth as my eyes roamed the still dark sky. Just over the horizon, John's great she-bear joined my ritual before fading into the dawn. I smiled in acknowledgment and wandered down the path picking raspberries and blueberries, placing them in my mouth as I went. My tongue crushed each berry against the roof of my mouth, their liquid sweetness dribbling down my throat.

Fingers suddenly wove into my hair, caressing my scalp, tugging back my head. I saw John's golden head above turn my black hair into its shadow. His lips and tongue hungered for the berries. Lips swollen red, I bent 
to pick another berry and another - tricking him into kisses. Blueberries for him raspberries for me. Teeth and tongues confusing lips for berries we exchanged and created tastes. Licking and biting until our mouths became purple and the bushes bare, we returned to the site. With arms shaped from earth and wind, John lifted me towards the sky and I wrapped my legs about his waist pressing the flesh of my thighs hard against his hipbones. I enjoyed his strength yet understood mine was greater. A man without a shadow is missing part of his soul. John sacrificed his shadow in his mother's grave, and I have clambered to bring it back to him. Souls are composite beings with various parts located in the blood, the heart, the secret name, the shadow. I have had to be shadow to many men. But mother and giver of souls only now to the child within my womb and the man at my breast.

Releasing my hold on his hips, I slid down his body until my toes touched the ground. He gave my hair a final tug and placed a purple kiss upon my forehead before turning to tend to the horses. Far from the world where fire would appear if I placed a cigarette at my lips, I searched the area for kindling and wood. Two horses grazed while John ran a brush over the flanks of the third mare. My fingers curled back the bark from the birch logs before chopping them into smaller pieces. John led the horses to the river and splashed his face while the mares touched their noses to the water. Shaping a miniature teepee in the fire pit, I put match to bark watching the flames writhe against the wood. Someone, I forget who, once said, "freedom is only the right to seek a further bondage." My eyes followed the flames as they curled in upon each other like tickled toes, like fiddlehead ferns, and I felt free.

Not like the man who appeared at our camp yesterday. Sergeant Flaherty was trapped in a world where the tall-tales and gossip of men replaced the whispers and sighs of the land. We welcomed him as a guest and shared a cut of caribou I had baked in the ground. He shielded his eyes pondering the meat as though it held answers to questions he struggled to voice. My mouth twitched and my eyes narrowed pinning him to the ground upon which he sat.

"Y-you miss that other life, Miss Ardith? The winters are pretty harsh fer a woman like yourself. You should think of headin back before winter catches you unawares."

The words choked from his throat, a stony sound, and John rose before 
I could form my reply.

"You tell them I'm not going back. Ever." No, I would never miss dancing in the clubs for diamonds. Or Saturdays spent in the beauty parlour. I would never miss three hour dinners at the Ritz or bubble baths at dawn. I would never miss Bloomingdales or Barneys, Bergdorf Goodman or Cartier. I would never miss carriage rides in Central Park. And champagne breakfasts. I would never miss the Dobbles grabbing at my tits. My past was only a route to my present. This present never becoming a past. Trembling with a conviction he could not hear, I knew he would misread my words as those of a woman who has taken the train one stop too far and is embarrassed to go back.

He mounted his pony and reached for the hand I extended. Pressing my fingers he said, "A ripe woman might perish in the wrong conditions. Come with me..."

My hand a trapped bird, it fluttered to be free of its cold cage and the man chuckled releasing his grasp. I stumbled backwards turning away without another glance.

From my place on the knoll, John looked a child idly skipping pebbles into the river. One pebble barely skipped before another followed in its wake. His hunched shoulders mirrored the slope of the riverbank while his moccasined toe hacked away at the earth searching to uproot another stone. One stone after another. Five skips. Four. Six. Two. The ripples of each blended over the other, a palimpsest of waves.

Hearing my approach his body was a deer ready to spring. His head never turned to meet my eyes. One more pebble skimmed across the water. Two... three... four times and sank. Winding my arms about his waist, I rested my cheek upon his back. My fingers raked down his chest from the base of his neck to the top of his pants. He moaned and turned and I could see the welts rising slightly where my nails had etched rivers of red in the brown of his skin. Then I was in the water. Arching, grinding, legs twisting, fingers clawing, mouths wide. My cry of "Kumkleseem" echoed across the lake.

We were to push further towards the mountains that day. I knew we had to be well into the comforting shelter of the rocks for I was getting large with child although the buckskin jacket camouflaged my form from Flaherty's eye. We packed the teepee and carried the loads towards the beckoning foothills. For weeks we hiked through the woods while the 
trees shed their cloaks of green and squirrels scurried about scavenging for acorns. My belly grew large, and I could feel the life inside nudging me, impatient and restless. The morning the mountain breathed the first wind of winter, a circlet of gold and crimson settled on its peak like an aureole nestled upon the head of an angel. My belly was ready to burst open as would a dandelion scattering its petals upon the land. I followed very slowly to our final winter resting place.

As the snow started tumbling, my belly started shifting. I groaned and doubled over. Frantically, John searched for shelter as the warm wetness trickled down my thigh like a tear. Protected by the embrace of spruce trees, I lay upon the toboggan biting the buckskin fringes of my jacket. Mother, how did you survive this so many times? I yearned then for her hand upon my cheek, that familiar lost touch which had comforted my measled body. Maybe if I closed my eyes I would be back in my pink bedroom. Mmmm. I snuggled into the blankets and nestled deeper into the snow. My cheek rested upon the feather pillow, my body warm beneath the down-filled comforter. Through the window framed with lace, I looked towards the barn where my father worked and I crossed the yard to join him. I had seen many calves born. Watched as my father yanked on the head and pulled out the sack, after. Stared as the calf struggled with her jelly legs. Clapped as she discovered her mother's teats.

Then I had to push. I pushed and pushed as the trees bent over to watch. As the mountain sturdy and unwavering bore witness. As the lake lay silent in wait. As the wind threw snow sideways like words. I looked down at the child dripping red roses on the white snow while John severed the cord with his knife. Placing the tiny body on my belly, he wrapped the shivering bawling flesh in a shirt of caribou hide. Another and another contraction pulsed and pulsed. A memory of the child itself.

We stayed for days. The winds pelted snow at the protecting arms of the trees until they were forced to weaken their hold. The elements gazed upon the sleeping face of the child. But we had to travel soon before the snow barricaded the pathway to our mountain cave. John loaded our possessions onto the toboggan and harnessed the child to his shoulders. In the crystalline dawn I began walking but by noon I was riding on the toboggan. Wind lashed my face, but the snow felt cool against my feverish cheek. I looked at myself and did not know my body, an abandoned cocoon deteriorating after the butterfly had gained its freedom. I wanted to close my nose to the smell my body was releasing. I was rotting from 
the inside.

Inside. Something inside was not working. My mind recalled the barn, the cow, the calf, the sack. I withered wanting to vomit what I knew had not completely left my body. What was decaying my guts. Then I did heave. Again and again leaving blotches along the trail. A sickened Gretel with no place to go back to. I desperately needed to see John and the child. Straining my neck and body against the cords that kept me from sliding off the toboggan, only a strap of the harness flapped into view. I rested my head back focusing on the strap, an echo of the child's heartbeat. As long as the strap kept beating there was hope.

The first stars began to dot the darkening sky as though innumerable fireflies were performing. Above me the great she-bear made her appearance. I winked at her and opened my mouth to catch the endless snowflakes upon my tongue. 